\title{
From Traces of Communism to Islets of Communism: Revisiting Althusser's Metaphors
}

\section{Introduction}

In 1976 Louis Althusser delivered a lecture at the Catalan College of Building Engineers and Technical Architects. In the Spanish translation of the text that appeared in a collection of Althusser's texts in 1978 there is a reference to "esbozos y sintomas de comunismo" (outlines and symptoms of communism), ${ }^{1}$ a phrase that also appears in the English translation of the text. ${ }^{2}$ When Althusser incorporated parts of this text in Les vaches noires (one of his unpublished manuscripts from the 1970s) he referred to "esquisses et promesses du communisme" (outlines and promises of communism). In the IMEC archives there is also another French version of the text that refers to "esquisses et traces du communisme" (outlines and traces of communism). ${ }^{4}$ It is also in Les vaches noires that we find another metaphor that would reappear in Althusser's texts. Althusser insists that "islets of communism already exist in the world" ("qu'il existe déjà dans le monde des îlots de communisme"). In an interview Althusser gave to Rossana Rossanda he speaks of "virtual forms of communism" emerging in those forms of associations that escape commodity relations.

All of these metaphors point to a preoccupation with how communist forms might emerge within capitalist societies. However, there are from the beginning

Louis Althusser, Nuevos escritos (La crisis des movimiento comunist internacional frente a la teoría marxista), Editorial Laia, Barcelona 1978, p. 54.

$2 \quad$ Louis Althusser, "Some Questions Concerning the Crisis of Marxist Theory and of the International Communist Movement”, trans. David Broder, Historical Materialism 23 (1/2015), p. 178.

3 Louis Althusser, Les Vaches noires. Interview imaginaire, ed. G.M. Goshgarian, PUF, Paris 2016, p. 248.

4 Louis Althusser, “Conférence sur la dictature de prolétariat à Barcelone. Un texte inédit de Louis Althusser”, Période (2014).

5 Althusser, Les Vaches noires. Interview imaginaire, p. 264.

6 Louis Althusser, Solitude de Machiavel, ed. Ives Sintomer, PUF, Paris 1998, p. 285.

* Hellenic Open University 
open questions with regard to this particular line of thinking in Althusser. Does this reference simply point to a quasi-metaphysical conception of the communist mode of production emerging out of the capitalist one, reproducing a version of the classical historicist idea of the 'necessary' succession of modes of production, or the idea that every mode of production carries the seeds of its aufhebung? In what sense do communist elements exist as traces or outlines? How are these related to a theory of transition and revolution? What is the actual meaning of the reference to "islets of communism"? In what follows I will try to show how these metaphors point to both Althusser's attempt to think through a "new practice of politics" for communism as well as to the limits of this thinking.

\section{Conditions for the existence and non-existence of a mode of production}

In order to discuss these questions we must first revisit a manuscript by Althusser from 1973, entitled "Book on Imperialism". This is part of a series of unpublished manuscripts by Althusser from the 1970s, which already included the basic aspects of the materialism of the encounter or aleatory materialism that was to be associated initially with the texts by Althusser from the $1980 \mathrm{~s}$ published posthumously. ${ }^{8}$ The importance of this manuscript is that it offers one of Althusser's most elaborate attempts to present a theory of the modes of production and of transition.

Althusser's starting point is an emphasis on the primacy of the relations of production over the forces of production and consequently the centrality of class struggle. However, it is interesting that Althusser starts the discussion on the mode of production with the assertion that "the socialist mode of production does not exist" and that in contrast "[t]he capitalist mode of production exists and the communist mode of production exists." Althusser insists that this was also Lenin's position:

7 Louis Althusser, History and Imperialism. Writings, 1963-1986, ed. and trans. G.N. Goshgarian, Polity, London 2020.

8 Louis Althusser, Philosophy of the Encounter: Later Writings 1978-86, trans. G.M. Goshgarian, Verso, London 2006.

9 Althusser, History and Imperialism, p. 63. 
[Lenin] defines this transition, this "socialist socioeconomic" formation, as the contradictory co-existence of the capitalist mode of production and the communist mode of production - thus as the co-existence of capitalist elements and communist elements, of elements of the communist mode of production and of the capitalist mode of production. ${ }^{10}$

Until this point, we are within positions that can also be found in the French debates of that period. Bettelheim used this as the starting point for his research on the Class Struggles in the USSR, ${ }^{11}$ and also Balibar would use this as an important part of his argument in On the Dictatorship of the Proletariat, ${ }^{12}$ namely the idea that socialism is a period of transition marked by intensified class struggle and the contradictory co-existence of two opposing modes of production, the capitalist mode and the emerging communist mode of production.

However, it is at this point that Althusser attempts to suggest that the communist mode of production exists from the moment the capitalist mode of production comes into existence:

Hence the question: when does communism begin to exist, understood as elements (or seeds, but seeds in the sense of seeds capable of producing elements)? Answer: from the moment the capitalist mode of production exists. This answer is, however, too generic, and is abstract. Yet it means (a thesis defended by Marx) that the capitalist mode of production contains the seeds of the communist mode of production in its own contradictions from the moment it comes into existence. More precisely, we can say that communism exists (begins to exist in a real sense) with the earliest developments of the workers' class struggle. Look at what Marx says in the [1844] Manuscripts about the French workers: society is no longer a means to an end, but a need. Look at everything Marx says about the disintegration of capitalist forms of the family, religion and so on. ${ }^{13}$

10 Ibid., p. 63.

${ }_{11}$ Charles Bettelheim, Class Struggle in the USSR, 2 vols., trans. Brian Pearce, Monthly Review Press, New York 1976-77.

12 Étienne Balibar, On the Dictatorship of the Proletariat, trans. Graham Locke, New Left Books, London 1977.

13 Althusser, History and Imperialism, p. 63. 
Althusser suggests that this is the result of the continuous effectivity of class antagonism inscribed in the capitalist relation of production. In this sense, an element of decomposition and disintegration of the capitalist mode of production is always present from the beginning.

The capitalist mode of production, which emerges on and from the decay of pre-capitalist modes of production (not just feudal, but other modes of production as well, and not just where there is no feudalism - for example, the Asiatic mode of production, the lineage-based mode of production, or the vestiges of the slave-based mode of production), itself decays from the moment it emerges, for a simple reason: the antagonism of the capitalist relation of production. This antagonism exists from the origin on and, from the origin on, produces effects of decomposition because of its antagonism (class struggle), which affects the forms of existence of the capitalist mode of production (division of labour, organization of labour, the family and other ideological state apparatuses). ${ }^{14}$

And here is how Althusser describes the communist elements emerging in the context of capitalism as a result of the class struggles of the working class.

The forms in which communist elements appear in capitalist society itself are countless. Marx himself names a whole series of them, from forms of children's education combining work and schooling to the new relations reigning in proletarian organizations, the proletarian family, the proletarian community of life and struggle, joint-stock companies, workers' co-operatives and so on, to say nothing of the "socialization of production", which poses all sorts of problems, yet should also be noted. All these elements (which have multiplied in the past few years, especially since 1968; see LIP, the proletarian inventions in the class struggle: "they have shown that the workers could do without bosses”, Séguy) will not by themselves lead to communism. Better: they are not all communist elements. They are elements for communism. Communism will adopt them, combine them, perfect them and develop their potentiality [virtualités], integrating them into the revolution in the relations of production which commands everything and is still absent from our world. Communism, however, will not come about by itself. It has to be

\footnotetext{
14 Ibid., pp. 63-64.
} 
built at the end of a long march, one stage of which is called socialism, which is not a mode of production. ${ }^{15}$

I think this passage is very important because it offers a rather complex theory of these elements for communism. The fact that Althusser insists that they are not communist elements but rather elements for communism points exactly towards the idea of communism being the outcome of a long period of transition.

In order to substantiate his position, Althusser attempts to offer elements of a theory of the mode of production. Of particular interest is the way he opposes any theory of simple commodity production / theory of the mercantile mode of production as a separate mode of production. We know how this theory, which in a certain way can draw on the authority of Engels's preface and supplement to Capital Vol. III, ${ }^{16}$ often returns in Marxist debates. However, Althusser also points out how the reference to the mercantile mode of production is also a basic reference within bourgeois ideology. Althusser insists that for bourgeois ideology:

[t]he capitalist mode of production is just the mercantile mode of production in its developed form, its naturally developed form: the mercantile mode of production serves to found the capitalist mode of production in bourgeois ideology, inasmuch as bourgeois ideology thinks the capitalist mode of production by way of the founding categories of the mercantile mode of production. ${ }^{17}$

For Althusser, this conception of the mercantile mode of production forms the background for the tendency of bourgeois ideology to present capitalism as the natural mode of production.

The capitalist mode of production, which exists, is the only one that can exist, the only one that exists, the only one that has a right to existence. The fact that it has not always existed (and even that must be qualified, for when we look into the matter in detail, we always find this reality, which is natural, everywhere: independent petty producers), or that it has not always visibly existed, obscured as it was by horrid realities - this is merely an accident of history. It should have

15 Ibid., pp. 64-65.

16 Karl Marx and Friedrich Engels, Collected Works (MECW), Lawrence and Wishart, London 1975-2005, vol. 37.

${ }_{17}$ Althusser, History and Imperialism, p. 88. 
existed from all eternity and, thank God, it exists today, having carried the day against obscurantism, and we may be sure that nature having finally vanquished non-nature, light having finally triumphed over darkness, nature and light, that is, the capitalist mode of production, can be sure of existing for all eternity. It has finally been recognized! ${ }^{18}$

Althusser does not deny the existence of independent petty producers. What he rejects is the position that these represent "the originary form of the capitalist mode of production." 19 His proposition is that there exists a form that may be termed "independent petty production" but "[t]here is nothing natural about this form" and "[t]his form can exist in different modes of production." 20

This elaboration gives Althusser the opportunity to return to what he defines as the "pseudo-mode of socialist production." ${ }^{21}$ His main point is that "in the socialist social formation there co-exist, in contradictory fashion, elements belonging to the capitalist relation of production and elements preparing for the communist relation of production." 22 But what are these elements that are preparing for the communist relation of production? Here is Althusser's answer:

The latter is prepared by collective ownership of the means of production and by a whole series of arrangements: the plan, guarantees that control the labour market, a wage structure that tends to reduce wage differentials and, generally speaking, organizational measures that tend to prepare communal forms of the management of enterprises and of the nation (measures that aim to attenuate and then do away with the division of labour, the division between mental and manual labour, the division between town and country and so on). ${ }^{23}$

For Althusser this suggests a broader non-historicist conception of the possibility but also of the non-possibility of a mode of production that is an integral part of a materialism of the encounter. Consequently, such a materialist theory of the emergence of capitalism presupposes

\footnotetext{
18 Althusser 2020, pp. 88-89.

19 Ibid., p. 92.

${ }^{20} \quad$ Ibid., p. 94.

${ }_{21}$ Althusser, History and Imperialism, p. 98.

$22 \quad$ Ibid., p. 98.

23 Ibid.
} 
that we have a certain idea of what it means to exist for a mode of production: the conditions of its existence - of its enduring reproduction - and of the relationship of this existence to non-existence. In other words, it presupposes that we have a clear understanding of the fact that a mode of production may not exist, may exist and perish as soon as it appears, or, on the contrary, may grow stronger and pursue its historical destiny. This presupposes a theory of the conditions of existence that is at the same time a theory of the conditions of the non-existence or disappearance of a mode of production. For we always reason on the basis of accomplished fact and nothing else. ${ }^{24}$

Although Althusser links this reference to his non-historicist conception of the emergence of the capitalist mode of production and the importance of thinking "on the basis of the accomplished fact," a point he would also make in his later texts on aleatory materialism, at the same time it can be considered an attempt by Althusser to rethink the possibility and non-possibility of a communist relation of production. This relation of existence to non-existence points exactly to a conception of history as an open-ended process, something that also points to the open character of any process of revolutionary change and transition to communism. Thus, the entire problematic of the 'socialist transition' should not be considered in the sense of 'building socialism' but in terms of a theory (and experimental practice) of the conditions for the existence and the conditions for the non-existence of communists relations and forms within 'transition processes' conditioned by class struggle.

For Althusser, modes of production do not necessarily find corresponding social formations that enable their reproduction. This can explain why elements of modes of production emerge but fail to achieve such social reproduction. This is a basic tenet of Althusser's conception of the centrality of the encounter and how an encounter might take place, might not take place, or might take place but not hold.

[N]ot every mode of production 'finds', automatically, by virtue of some sort of divine right or ontological argument (which would have it that every essence is fully entitled to exist, that every mode of production exists by virtue of its essence), the form in which it can exist. If it 'finds' that form, that is, if existing conditions

24 Ibid., p. 103. 
allow it to endow itself with existence, to realize its existence, to 'forge' it, then the mode of production in question will exist. If it fails to find that form, if existing conditions do not allow it to realize it, to impose it, then the mode of production will not exist. Or if it has begun to exist for a time but, at the end of the prescribed period (for in these matters Spinozist necessity is unrelenting), has not managed to endow itself with the form of social formation corresponding to it, that is, the form that allows it to reproduce itself in either simple or extended form, then the mode of production in question will perish. ${ }^{25}$

For Althusser, this also goes for the communist mode of production and its historical possibility. That is why it is important for Althusser "to compare the cases of existence with the cases of non-existence (in the sense indicated above) and think the conditions of existence setting out from the conditions of non-existence." ${ }^{26}$ This points, in my reading, to Althusser at the same time thinking all the failures and shortcomings of 'actually existing socialism' and, by means of this, rethinking how the communist elements or the elements for communism can actually be transformed into communist social forms that could last. Moreover, it points towards the necessity of thinking the very contradictory character of any transition process, the constant and uneven antagonistic confrontation between capitalist and communist relations and forms, but also the equally constant and uneven class struggles involved, as well as the fact that there is nothing predetermined in this process.

This is not without political consequences, with all due respect to specialists of the accomplished fact. For (to come back to the case before us, socialism) it can tell us something about the conditions of existence of an embryonic mode of production setting out from the conditions of its non-existence. This contradictory situation is very interesting, for - what a surprise! - it simply repeats Lenin's theory on the 'transition' from capitalism to communism. In socialism, the conditions for the non-existence of communism have all been met and are there for all to see: they are the subsisting elements of the capitalist mode of production. Of course, they exist in "different forms" (Lenin), as do the classes and the class struggle; of course, they exist in "different forms" - Marx would have [said] 'transformed forms'. Yet they are there, and are not imaginary at all, but very

\footnotetext{
25 Ibid., pp. 128-129.

$26 \quad$ Ibid., p. 132.
} 
real and active. And it is clearly on condition that we 'resolve', in the right sense (in the right direction, thanks to a well-oriented political line), this contradiction between the conditions of existence and the conditions of non-existence of the communist mode of production that we will some day reach the communist mode of production. As for those who think that everything has already been decided in advance (as the destiny of the capitalist mode of production was decided in advance as soon as it came into existence, the proof being that, when it happened to perish because the conditions of its existence had not been fulfilled, one says it never existed - it is so easy to suppose, in this way, that all the dead never existed!), they need only reread Lenin, who said: we can fall back rather than advancing towards communism; we can "cool our heels" [faire antichambre] in a socialism which, because it has stopped advancing, retreats. It really seems to me that Lenin had understood the interest of this little question about the conditions of the non-existence (or death) of a mode of production fairly well. I mean the political interest (for, thank god, Lenin, at least, was not given to speculation). ${ }^{27}$

Consequently, for Althusser "the question of the existence of a mode of production in a social formation is posed only as a function of this contradictory couple: conditions of its non-existence/conditions of its existence." ${ }^{28}$ However, it is also obvious that Althusser at this point insists on the fact that the elements for communism can be transformed into communist social forms only after a long process of struggle and transformation.

It is also interesting that later in this manuscript Althusser returns to this point. Althusser here deals with how Marx insists on only discussing phenomena in their pure essence. Althusser believes that Marx here refers to a process of scientific experimentation.

Yet Marx does nothing other than what any scientist does. He 'isolates' the mechanism that he has succeeded in identifying as essential; he isolates it from all details that might alter its course in an accidental, not an essential way; and he analyses the phenomenon in its 'pure form'. Just like the physicist who analyses the law of falling bodies, to take a simple example, he ignores everything that does not concern the phenomenon in its pure form (friction and so on). He thus creates

\footnotetext{
${ }_{27}$ Ibid., pp. 132-133.

28 Ibid., p. 133.
} 
the conditions for true scientific experimentation; the fact that it is purely conceptual experimentation changes nothing here. It is indeed an experiment in which the scientist Marx allows the elements to vary after isolating them as pertinent. ${ }^{29}$

Although Althusser here mainly refers to Marx's attempt to theorize the capitalist mode of production, it is also possible to think that Althusser here also in a certain way is referring to the transition to communism as a process of experimentation, something that Marx also suggested in the Critique of the Gotha Program.

The question then arises: what transformation will the state undergo in communist society? In other words, what social functions will remain in existence there that are analogous to present state functions? This question can only be answered scientifically, and one does not get a flea-hop nearer to the problem by a thousandfold combination of the word people with the word state.

Between capitalist and communist society lies the period of the revolutionary transformation of the one into the other. Corresponding to this is also a political transition period in which the state can be nothing but the revolutionary dictatorship of the proletariat. ${ }^{30}$

Consequently, I would like to suggest that the theoretical line that we can find in Althusser's Book on Imperialism is exactly a conceptualisation of the question of the potential communist mode of production in terms of the contradictory and antagonistic co-existence of capitalist and communist relations in a transition period, a period that can only be described as a 'long march' of constant struggle and experimentation. This conception is also echoed in Balibar's arguments in his book on the dictatorship of the proletariat.

That is why it produces nothing but confusion to picture socialism in terms of the simple 'rationalization' of the organization of social labour, the parasitic capitalist class having been eliminated (even if this process is supposed to be accompanied, at the social level, by a fair distribution of the products of labour, and at the political level by greater liberty and increased 'participation' for the masses). Such

29 Ibid., p. 143.

3о Marx and Engels, Collected Works (MECW), vol. 24, p. 95. 
a picture leaves out the essential point: that socialism, as an historical process, can only develop on the basis of a profound, progressive transformation of the division of labour, on the basis of a conscious political struggle against the division of manual and intellectual labour, against 'narrow' specialization, for what Marx called 'all-round competence'. Socialism cannot consist in the permanent association, in the service of their common interest, of the various social strata and categories of 'working people' existing in capitalist society: it cannot perpetuate, or even 'guarantee' the distinctions in function and status which divide them, as if there always had to be engineers on the one hand and unskilled workers on the other, professors, lawyers and labourers ... It can only be the continuous process of the transformation of these divisions, which will finally suppress the foundations of all competition, in the capitalist sense of the term, between working people, therefore the very foundations of wage labour and consequently the bases of commodity production, whether planned or not. In an earlier chapter I talked about the constitution of the proletariat as a class in terms of a process which can only 'end' with the constitution of the proletariat as the ruling class. It seems to me that it is therefore now time to propose the following argument: socialism is a process in the course of which the condition of the proletariat becomes generalized at the same time as it is transformed and tends to disappear. This is, in both senses of the term, the end point of the formation of the proletariat. ${ }^{31}$

\section{Communism in the margins}

However, there is also another emerging tendency in Althusser's thinking of the emergence of potential communist forms. This has to do with the various references to the margins. We know that Althusser always referred to Marx's passage in Vol. I of Capital about commodity relations emerging in the interstices of pre-capitalist modes of production. Here is the passage from volume one of Capital.

In the ancient Asiatic and other ancient modes of production, we find that the conversion of products into commodities, and therefore the conversion of men into producers of commodities, holds a subordinate place, which, however, increases in importance as the primitive communities approach nearer and nearer

${ }^{31}$ Balibar, On the Dictatorship of the Proletariat, pp. 149-150. 
to their dissolution. Trading nations, properly so called, exist in the ancient world only in its interstices, like the gods of Epicurus in the Intermundia. ${ }^{32}$

We have seen that this can be read in the sense of a non-historicist conception of the emergence of social forms and potential antagonistic forms of production and as part of a materialism of the encounter. However, there is also Althusser's interest in the image of the margin.

This is evident in his 1976 manuscript How to be a Marxist in Philosophy. ${ }^{33}$ An important segment of this manuscript is dedicated to a discussion of the image of the margin. This segment is Althusser's attempt to rethink how different philosophical systems include a notion of Order, but also a notion of the limits of this Order, i.e. the particular relation between the inside and the outside:

We must accordingly find the means, and it is not easy, to think, simultaneously, the Order which is round, and thus limited by its curve, and the not-outside, that is, the absence of curves and limits. A limit that is, in sum, a non-limit, a circle that is a circle, but with no outside..$^{34}$

With regard to this notion of the limit, Althusser first turns towards Heidegger, whose thinking on the question of the limit he finds interesting, while at the same time he thinks Heidegger "acknowledges the issue, but thrashes around in rather than resolving it, since, instead of maintaining a healthy balance, he assigns Being primacy over beings, like the good spiritualist that he has basically continued to be.”35 Instead, Althusser turns towards Derrida.

Derrida has very convincingly shown that we must look to the margin for the answer to the question of a limit that is not a limit. Everybody knows what a margin is: there is one on this very page, an empty space alongside a full one. You would think that fullness could not do without emptiness, and the other way around. This presupposes a limit between the two, of course, but a limit that is not an Order or, at any rate, does not derive from an Order, since we can vary the margin,

32 Marx and Engels, Collected Works (MECW), vol. 35, p. 90.

33 Louis Althusser, How to be a Marxist in Philosophy, trans. G.M. Goshgarian, Bloomsbury, London 2017.

34 Ibid., p. 86.

35 Ibid., p. 87. 
and thus the limit. It makes no difference whether the margin is two centimetres wide, or three; it's enough to come to an agreement with the compositor, and you're all set. Derrida has seen, then, that this 'play' matters to the margin, quite as much as the margin matters to the limit. But this 'play' of course changes everything, since it is free, not constrained; thus it frees itself and frees us of all Order, flat or round, monist or dualist, or even twisted. ${ }^{36}$

However, Althusser does not limit himself to this appreciation of Derrida and his conception of the margin..$^{37}$ For Althusser, the margin becomes here the central part of an almost poetic thinking of the emergence of new social forms and communist virtualities within capitalist formations.

This margin is now beginning to sustain our hopes, after being subjected to our despair. For what is in the margin is marginal: the mad, children, deviants, philosophers, the mentally ill, deranged or normal artists, the abnormal and so on. And it turns out that, once normality has been demystified (Canguilhem has done a great deal to help us understand this, after Spinoza and Nietzsche), one suddenly realizes that interesting things go on in the vicinity of the margin: on the margin of official society, where the exploited workers and the immigrant workers are, together with children, from whose mouths the truth has long come, and artists, from the greatest to the humblest, with Breton and his friends in-between, and the poor in spirit when they are saints, even if they don't know it, and the mad, and certain prisoners, Soviet and Latin American prisoners in particular and so on. The margin is also the beach, the one on which everyone will alight to enjoy the sun after we have at last crossed this terrible river of socialism in the boat of the dictatorship of the proletariat. And then we shall have the free reign of the margin on the beach of communism: there will be no more written texts, no more written right, no more written law, no more written orders, no more writing, nothing but living traces, traces of the spoken word, exchanges of words and goods without money, without (written) accounts, exchanges of looks and voices, of love or hate, with no dishonest descriptions of the merchandise. This will be

${ }^{36}$ Ibid., pp. 87-88.

37 For Derrida's conception of the margin see Jacques Derrida, Margins of philosophy, trans. Alan Bass, Harvester Press, London 1982. 
the end of the dictatorship of writing, the end of the dictatorship of language, the reign of the universal margin and the universal family.38

Moreover, Althusser insists that this emergence of new social forms at the margins is something that is already happening, and that it is not just some type of utopian thinking.

What is encouraging - for I know you, you're going to say I'm raving - is that the margin is no utopia; it exists today, well and truly, in reality. Witness not just Derrida's theory, but the existence of all the marginal sorts, in the official statistics or not. It exists and is developing in every country - yes, in every country, even the USSR. I shall explain that to you some day; unfortunately, I don't have the time today. If that isn't a way of saying that Derrida hasn't missed the mark in putting the question of the margin in the command post! The interest of Derrida's research resides in the demonstration that philosophy and politics are, in a certain regard, the same thing. The fact that a theory of the margin such as his leads straight to an encounter with the theory of politics and, from a certain angle, anticipates communism, proves this, quite obviously, with no need for comment. ${ }^{39}$

After some references to how science can offer ways to think of new forms, Althusser does not elaborate more on the subject, calling on us to be "sure that the work of the sciences, the reflections of the philosophers, and the imagination of artists and politicians will know how to pursue it and make it more precise."40

Leaving aside the poetic overtones of some of the formulations, it is obvious that Althusser, with this imagery of the margin, attempted to think through this idea of elements of communism emerging in struggles and movements. However, what is missing with regard to the formulation concerning communist elements

38 Althusser, How to be a Marxist in Philosophy, p. 88 The paragraph ends with a strange invocation of universal whiteness. 'I tell you, the reign of whiteness, which one will see in the whites of people's eyes, the universal reign of whites, that is, of the white race, but all the races will be white [blanc], that is, all colours, and only the wise guys [blancs-becs, literally, white beaks] will have to watch their behaviour, unless they turn into Prince Charmings [merles blancs, literally, white blackbirds]. What is more, all blackbirds will be white: black will be suppressed, along with all the mourning and suffering it is possible to avoid (Ibid., p. 88).

39 Ibid., pp. 88-89.

$40 \quad$ Ibid., p. 90. 
in Book on Imperialism is this idea of a 'Long March' of a processes of struggles, confrontations, and experimentation, as part of a transitional period of intensified class struggles, which would also have as a starting point a revolutionary rupture.

It is true that in the second half of the 1970s Althusser often stressed the importance of initiatives of the masses. In his intervention in the debate at the $22^{\text {nd }}$ Congress of the French Communist Party Althusser insisted on the importance of

restoring their voice to the masses who make history. Not just putting oneself 'at the service of the masses' (a slogan which may be pretty reactionary), but opening one's ears to them, studying and understanding their aspirations and their contradictions, their aspirations in their contradictions, learning how to be attentive to the masses' imagination and inventiveness..$^{41}$

However, at the same time Althusser also concentrated on another crucial aspect that perhaps can explain the imagery of the margin. This is the fact that many of the popular initiatives that represented for him a hopeful way out of the crisis of the communist movement were happening outside the official parties and trade unions. This poses a grave problem for him, in both the East and the West.

In the East as in the West we are confronted with the grave problem of the relation existing between these organizations and the State: with the problem, in the East, of the fusion of these organizations with the State, an open fusion; with the problem, in the West, of the risk of fusion, because the bourgeois State never stops trying to integrate the organizations of class struggle of the working class into its own operations, often with success. ${ }^{42}$

Consequently, Althusser in the same text, the text of his 1977 Venice intervention on the crisis of Marxism, insists that this is the crucial question:

And above all - the most important of questions for past and future - how can relations be established with the mass movement which, transcending the tradi-

${ }_{41}$ Louis Althusser, "On the Twenty-Second Congress of the French Communist Party", New Left Review (July 1977), p. 11.

42 Louis Althusser, “The Crisis of Marxism”, Marxism Today (July 1978), p. 220. 
tional distinction between trade union and party, will permit the development of initiatives among the people, which usually fail to fit into the division between the economic and political spheres (even 'added together')? Because we are witnessing more and more mass movements of the people arising by themselves, outside of the trade unions and parties, bringing - or capable of bringing - something indispensable to the struggle. In short, how can we properly respond to the demands and expectations of the masses of the people?43

So one might say that this increased importance of the imagery of the margin is one way for Althusser to suggest the difficulty posed by the fact that the autonomous initiatives of the masses emerge outside the traditional organization and political forms associated with the working class movement, thus making it even harder to actually think how it is possible to transform the elements for communism into a transitional process. Thus, the reference to communist forms actually emerging in the margins or interstices or the reference to communist islets is one way to emphasize the dynamic of these elements, even in a manner that seemingly at least overlooks the question of the organizational forms. Or one might suggest that this is exactly Althusser's way of pointing to the radical political and organizational novelty and ingenuity required to actually transform the 'traces of communism' into a feasible strategy for communism.

\section{Islets of communism}

However, he, at least in some of his texts and interventions, seems to turn more towards this conception of communism already existing in the interstices of contemporary societies. A 1980 letter offers an almost poetic vision of an already existing communism in those practices and relations that escape the commodity relation.

I am in Greece with friends. In Athens. What a wonderful country: the beauty of the city under the sun, and now the storm: a splendour, I see the city from the apartment, and I am listening to Beethoven's $7^{\text {th }}$ Symphony on the radio. Only the sea, the islands, and the beach are missing. The woman I love is with me. Friends will come, wonderful. I am happy and communism is within reach.

43 Ibid. 
Communism exists today in all places where

1) there is no commodity relation

2) therefore no economic exploitation

3) therefore no political domination

4) therefore no ideological servitude or intimidation

It exists everywhere in the world, in the islets of friendship (between all the friends that love each other and talk about what interests them, between all the children that play, between all the men that play football or other games where it is about winning by respecting the rules of the game, without hurting anyone. Communism is respect for others, when all relations of exploitation, domination and intimidation have been suppressed or suspended. ${ }^{44}$

The same tone emerges in all the accounts we have from Althusser's intervention in a debate at Terni in Italy again in 1980. Chistian Lo Iacono has attempted to offer a reconstruction of this intervention by looking at the reports in various newspapers.

On 4 April 1980 one can read in the Italian newspapers various accounts of a debate that took place during the "Study days at the Paris Commune", organized by political and artistic collectives of the Terni steelworks. Althusser took part in them with his old friend Cesare Luporini. The film recording has been lost, but there are reports of extensive segments, the most significant. In any case, a comparative reading of the different newspapers leaves no doubt as to what Althusser said. He overwhelms his listeners with a radicalism that, according to witnesses, overflows into delirium. They describe a frenetic Althusser as he waits to take the floor. He poses as an interpreter who almost disappears behind the 'voices' and 'actions' of which he is the bearer. The protagonists are the mass movements that all over the world play on a political scene completely different than that dominated by the system of representation, be it democratic or bureaucratic. Despite the insufficient documentation at our disposal, it is very clear that he had an idea of politics far removed from that of the slow activity of institutional transformation. Above all, there is the idea of the paradox of politics, of its impossibility (indeed, the Machiavellian idea of "occupying the place

44 Louis Althusser in William S. Lewis, « Sur un voyage en Grèce”, 2018, available at: https:// www.imec-archives.com/papiers/william-lewis/. 
of the impossible”). "Never," he said, "in history has there been verified such a favourable situation as the present [...]. The military forces of the great powers [...] cancel each other out, mutually paralyze each other; Western communist parties and workers' organizations are at an impasse, cannot move, therefore, the space for revolution is free: the only thing is to know what we want, and to want it by thinking reality as it is." 45

And again we have the image of communism already existing everywhere, and of the islets of communism already existing in the interstices of society.

Communism exists "everywhere - even here, today, in Terni, or in a church, or on a field where football is played - there where real relationships, are created, islets of communism characterized by three conditions: no economic exploitation, no pressure from political power, no ideological servitude." "Otherwise," Althusser adds, "socialism is crap." Communism is not eclipsed, on the contrary, "the future is played in our head," on condition of defeating all "paper tigers," all "misconceptions."

The similarity between the citations in the journalistic reports and the letter mentioned above suggests that the reports are rather accurate. Moreover, we also have similar references in his interview with RAI 30 of April 1980.47 In a certain way, this idea of already existing communism in the islets of communism emerging in contemporary capitalist societies combined with this emphasis on the actual strength of popular initiatives (a recurring theme in his interventions from that period) is Althusser's 'bending the stick to the other side. It represents Althusser's attempt to escape the difficulty of rethinking the political, theoretical, and ideological conditions in order to overcome the deep crisis of the existing communist parties and mass organisations.

45 Christian Lo Iacono, “Un amour compliqué avec les marxismes dissidents italiens”, 2015, available at : La Pensée 382, https://www.cairn.info/revue-la-pensee-2015-2-page-139.htm.

46 Ibid.

47 Louis Althusser, "The Crisis of Marxism: An interview with Louis Althusser”, trans. Ron Salaj, 2017, available at: https://www.versobooks.com/blogs/3312-the-crisis-of-marxisman-interview-with-louis-althusser. 


\section{The margin and underdetermination}

To return to the imagery of the margin, it is interesting how Althusser also linked it to the notion of underdetermination. Here is a relevant reference in a 1984 letter to Fernanda Navarro:

Of course there are, as you say, 'possibilities' within social determination, if only because there are several different orders of social determination and because this creates a play - of gaps, blank spaces, or margins in which the subject may find his path determined or not determined by social constraints; but this non-determination is an effect, a sub-effect, of determination, of determinations; what I called not only overdetermination, but underdetermination ... Do you see what I mean?48

For Althusser, the notion of underdetermination refers exactly to the uneven character of class struggle and antagonism and how the working class is not just the opposite of the capitalist class.

[I] fou take seriously the nature of the Marxist whole and its unevenness, you must come to the conclusion that this unevenness is necessarily reflected in the form of the overdetermination or of the underdetermination of contradiction. [...] [C]ontradiction, as you find it in Capital, presents the surprising characteristic of being uneven, of bringing contrary terms into operation which you cannot obtain just by giving the second a sign obtained by negating that of the first. This is because they are caught up in a relation of unevenness which continuously reproduces its conditions of existence just on account of this contradiction. [...] Because the working class is not the opposite of the capitalist class, it is not the capitalist class negated, deprived of its capital and its powers - and the capitalist class is not the working class plus something else, namely riches and power. They do not share the same history, they do not share the same world, they do not lead the same class struggle, and yet they do come into confrontation, and this certainly is a contradiction since the relation of confrontation reproduces the conditions of confrontation instead of transcending them in a beautiful Hegelian exaltation and reconciliation. ${ }^{49}$

48 Louis Althusser, Philosophy of the Encounter: Later Writings 1978-86, trans. G.M. Goshgarian, Verso, London 2006, p. 236.

49 Louis Althusser, Essays in Self-Criticism, trans. Grahame Locke, New Left Books, London 1976, pp. 184-5. 
Étienne Balibar has suggested that this 'enigmatic' reference in the 1975 Soutenance d'Amiens must be read as suggesting a philosophical programme to think, besides the "necessity of contingency," also "the contingent of this contingence, the 'under-determined' multiplicity of possibles or tendencies that coexist within the same event."50 I think that apart from the broader implications that the notion of underdetermination has for any theorization of historical dynamics that do not manage to reach a certain threshold of determination, it also points to the very unevenness and difficulty of any attempt to transform subaltern resistances and aspirations into a historical initiative capable of social change.

\section{The inescapable tension}

In this sense and contrary to some of Althusser's more enthusiastic passages, the communist elements at the interstices or the margins and the islets of communism point to both the possibility and impossibility of communism. They point to dynamics that are constantly reproduced, but also to counter-dynamics and political, ideological, and institutional obstacles thereto, beginning with the very weight of previous defeats. This can explain both the constant observation of such traces of communism and at the same time all of the effects of the miscognition, disorientation, disillusionment, and disaggregation of the subaltern classes and groups.

That is why it is important to stress the tension running through such references by Althusser and how they point to both an actual attempt to rethink communism as the limit of class antagonism and of the constant resistance and struggle inscribed at the heart of the capitalist relation of production, and to a certain desire to bypass the complex political labour of creating the conditions to turn these elements into new social forms and relations, i.e. all the effort associated with assembling the modern Prince and rethinking transition as both struggle and experimentation.

If we could discuss this tension in another way, we could say that on the one hand we have Althusser trying to expand his original politico-theoretical project of recreating the possibility of a fusion between the working class and Marxism,

50 Étienne Balibar, “Avant-propos”, in Louis Althusser, Pour Marx, La Découverte/Poche, Paris 1996, p. xiii. 
by means of a radical renewal of the communist movement, even in the sense of new movements outside official communist parties. On the other hand, the realisation of the extent of the rupture between the subaltern classes and both Marxist theory and communist political organisations led Althusser to a conception of the encounter as almost chance, including the imagery of islets of communism, which is closer to Derrida's suggestion of an eschatology without teleology than to a non-teleological materialism of the encounter. Here is how Derrida puts it:

To this extent, the effectivity or actuality of the democratic promise, like that of the communist promise, will always keep within it, and it must do so, this absolutely undetermined messianic hope at its heart, this eschatological relation to the tocome of an event and of a singularity, of an alterity that cannot be anticipated. [...] It would be easy, too easy, to show that such a hospitality without reserve, which is nevertheless the condition of the event and thus of history (nothing and no one would arrive otherwise, a hypothesis that one can never exclude, of course), is the impossible itself, and that this condition of possibility of the event is also its condition of impossibility, like this strange concept of messianism without content, of the messianic without messianism, that guides us here like the blind. But it would be just as easy to show that without this experience of the impossible, one might as well give up on both justice and the event. That would be still more just or more honest. One might as well give up also on whatever good conscience one still claims to preserve. One might as well confess the economic calculation and declare all the checkpoints that ethics, hospitality, or the various messianisms would still install at the borders of the event in order to screen the arrivant..$^{1}$

However interesting Derrida's attempt to rethink an eschatological although non-teleological conception of communism is, it is obvious that we are moving beyond the idea of a political process elaborating and transforming social dynamics and struggles into a transitional process and strategy for communism. This can also be considered to be an indication of the tensions and limits of Althusser's thinking within the context of the philosophy of the encounter.

${ }^{51}$ Jacques Derrida, Specters of Marx. The State of the Debt, the Work of Mourning and the New International, trans. Peggy Kamuf, Routledge, London 2006, pp. 81-82. See the discussion in Étienne Balibar, 'Eschatology versus Teleology: The Suspended Dialogue between Derrida and Althusser', in Derrida and the Time of the Political, ed. Pheng Cheah and Suzanne Guerlac, Duke University Press, Durham 2009. 
It is the same tension that we find in Althusser's constant return to Machiavelli. On the one hand, Machiavelli, for Althusser, is an attempt to rethink the very idea of a new practice of politics that is able to deal with the complexity of the conjuncture, both its overdetermination and underdetermination, in order to create the conditions for a radical change in the relation of forces. On the other hand, there is a conception of radical and emancipatory politics as pure novelty, as a radically novel political gesture, a solitary political act that initiates a new political sequence. ${ }^{52}$

Althusser never published Machiavelli and Us. Perhaps this had to do with these tensions. Perhaps it was the weight of the realisation that the need for a politics of radical novelty and the creation of the conditions for fortunate encounters between struggles, strategy, and social dynamics could only be answered by a painful and thorough recomposition of the political organisations of the working class, a task well beyond a simple call for a left-wing turn of the actually existing communist movement and also beyond simply investing in the expansion of already existing islets of communism.

In a certain sense, Althusser's references to traces or elements of communism point to both an indispensable starting point for any strategy for communism and all the open questions associated with the very idea of a political practice with a communist horizon. Retracing the tensions running through Louis Althusser's confrontation with these questions is also a way to rethink a challenge that is more actual and urgent than ever.

\section{References}

Althusser, Louis, “Conférence sur la dictature de prolétariat à Barcelone. Un texte inédit de Louis Althusser”, Période (2014), available at: http://revueperiode.net/un-texte-inedit-de-louis-althusser-conference-sur-la-dictature-du-proletariat-a-barcelone/

- Essays in Self-Criticism, trans. Grahame Locke, New Left Books, London 1976

- History and Imperialism. Writings, 1963-1986, ed. and trans. G.N. Goshgarian, Polity, London 2020

- How to be a Marxist in Philosophy, trans. G.M. Goshgarian, Bloomsbury, London 2017

- Les Vaches noires. Interview imaginaire, ed. G.M. Goshgarian, PUF, Paris 2016

52 On these tensions see Panagiotis Sotiris, A Philosophy for Communism. Rethinking Althusser, Brill, Leiden 2020. 
- Machiavelli and Us, trans. Gregory Elliott, Verso, London 1999

- Nuevos escritos (La crisis des movimiento comunist internacional frente a la teoría marxista), Editorial Laia, Barcelona 1978

- "On the Twenty-Second Congress of the French Communist Party", New Left Review 104 (July 1977)

- Philosophy of the Encounter: Later Writings 1978-86, trans. G.M. Goshgarian, Verso, London 2006

- Solitude de Machiavel, ed. by Ives Sintomer, PUF, Paris 1998

- 'The Crisis of Marxism', Marxism Today (July 1978)

- "Some Questions Concerning the Crisis of Marxist Theory and of the International Communist Movement”, translated by David Broder, Historical Materialism 23 (2015), No. 1

- "The Crisis of Marxism: An interview with Louis Althusser”, trans. Ron Salaj, 2017, available at: www.versobooks.com/blogs/3312-the-crisis-of-marxism-an-interviewwith-louis-althusser

Balibar, Étienne, “Avant-propos”, in Louis Althusser, Pour Marx, La Découverte/Poche, Paris 1996

- "Eschatology versus Teleology: The Suspended Dialogue between Derrida and Althusser", in Derrida and the Time of the Political, ed. Pheng Cheah and Suzanne Guerlac, Duke University Press, Durham 2009

- On the Dictatorship of the Proletariat, trans. Graham Locke, New Left Books, London 1977

Bettelheim, Charles, Class Struggle in the USSR, 2 vols., trans. Brian Pearce, Monthly Review Press, New York 1976-77

Derrida, Jacques, Marges de la philosophie, Seuil, Paris 1972

- Margins of Philosophy, trans. Alan Bass, Harvester Press, London 1982

- Specters of Marx. The State of the Debt, the Work of Mourning and the New International, trans. Peggy Kamuf, Routledge, London 2006

Lewis, William S., "Sur un voyage en Grèce”, 2018, available at: https://www.imec-archives.com/papiers/william-lewis/

Lo Iacono, Christian, "Un amour compliqué avec les marxismes dissidents italiens", 2015, available at: La Pensée 382, https://www.cairn.info/revue-la-pensee-2015-2page-139.htm.

Marx, Karl and Friedrich Engels, Collected Works (MECW), Lawrence and Wishart, Leiden 1975-2005

Sotiris, Panagiotis, A Philosophy for Communism. Rethinking Althusser, Brill, Leiden 2020 